\title{
In vitro anti-Mycobacterium tuberculosis activity of some Brazilian "Cerrado" plants
}

\author{
Fernando R. Pavan, ${ }^{* 1}$ Daisy N. Sato, ${ }^{2}$ Célio T. Higuchi, ${ }^{1}$ Adolfo C. B. Santos, ${ }^{1}$ \\ Wagner Vilegas, ${ }^{3}$ Clarice Q. F. Leite ${ }^{*, 1}$
}

${ }^{1}$ Departamento de Ciências Biológicas, Universidade Estadual Paulista Julio de Mesquita Filho, Faculdade de Ciências Farmacêuticas, 14801-902 Araraquara-SP, Brazil,

${ }^{2}$ Laboratório de Micobacteriologia, Instituto Adolfo Lutz, Rua Minas, 887, 14085-410 Ribeirão Preto-SP, Brazil,

${ }^{3}$ Departamento de Química Orgânica, Universidade Estadual Paulista Julio de Mesquita Filho, Instituto de

Química de Araraquara, Caixa Postal 335, 14800-900 Araraquara-SP, Brazil

\begin{abstract}
RESUMO: "Atividade anti-Mycobacterium tuberculosis in vitro de algumas plantas do "Cerrado" Brasileiro". O objetivo deste trabalho foi realizar uma seleção de algumas plantas de uma determinada região Brasileira com atividade contra Mycobacterium tuberculosis. Extratos clorofórmicos e metanólicos de 37 espécies de plantas distribuídas em 17 famílias do "Cerrado" Brasileiro foram avaliadas contra $M$. tuberculosis $\mathrm{H}_{37} \mathrm{Rv}$ e a Concentração Inibitória Mínima (CIM) foi determinada pelo uso do Microplate Alamar Blue Assay (MABA). Extratos brutos de dezesseis plantas apresentaram valor de CIM $\leq 125 \mu \mathrm{g} / \mathrm{mL}$ e três de $31,2 \mu \mathrm{g} / \mathrm{mL}$. Estes resultados sugerem que o "Cerrado" Brasileiro deve possuir um recurso de plantas com constituintes ativos anti-M. tuberculosis que podem ser extraídos por solventes polares e apolares.
\end{abstract}

Unitermos: Plantas do Cerrado Brasileiro, Mycobacterium tuberculosis, atividade antituberculose, MABA.

\begin{abstract}
The aim of this work was to carry out a screening of some plants of this Brazilian region with activity against Mycobacterium tuberculosis. Chloroform and methanol extracts of 37 plant species distributed among 17 families from Brazilian "Cerrado" which were tested against M. tuberculosis $\mathrm{H}_{37} \mathrm{Rv}$ and the Minimum Inhibitory Concentration (MIC) was determined by the use of Microplate Alamar Blue Assay (MABA). Crude extracts from sixteen plants showed MIC value of $\leq 125 \mu \mathrm{g} / \mathrm{mL}$ and three $31.2 \mu \mathrm{g} / \mathrm{mL}$. These results suggest that the Brazilian "Cerrado" may be a source of plants that have activity anti-M. tuberculosis constituents that can be extracted by polars and apolars solvents.
\end{abstract}

Keywords: Brazilian "Cerrado" plants, Mycobacterium tuberculosis, antitubercular activity, MABA.

\section{INTRODUCTION}

Tuberculosis (TB) continues to be the leading cause of worldwide death due to an infectious agent. The rapid spread of multidrug resistant TB (MDRTB) strains around the world have showed the urgent need for the development of new TB drugs to shortening the duration of the treatment and the fight against MDRTB strains (Tripathi et al., 2005).

Natural products and/or their semi-synthetic derivatives can lead to novel antimycobacterial drugs and may have important roles in the chemotherapy of tuberculosis. Some recent reports have demonstrated the in vitro bioassay activity of plant-derived terpenoids against M. tuberculosis (Higuchi et al., 2008; Cantrell et al., 2001). The literature also reports the antimycobacterial activity of many classes of natural products: such as alkanes, phenolics, acetogenic quinines, flavonoids and triterpenes (Copp, 2003).

Having savannah as vegetation, Brazilian Central Cerrado, is one of the major biogeographical regions of the world with more than 7,000 native species of vascular plants (Mendonça et al., 1998). Many of these plants are commonly used as natural drugs by the people who live in the Cerrado area to treat several illnesses (Almeida et al., 1998), including some verbal relates for TB treatment. The aim of this work was to carry out a screening of some plants of this Brazilian region with activity against Mycobacterium tuberculosis.

\section{MATERIAL AND METHODS}

\section{Plant materials}

The fresh leaf, bark, fruits, chapter and scapes 
Table 1. Plants from Brazilian "Cerrado" and screening of MIC values of their chloroform and methanol extracts against Mycobacterium tuberculosis $\mathrm{H}_{37} \mathrm{Rv}$ ATCC 27264.

\begin{tabular}{|c|c|c|c|}
\hline Plants & Plant Part & $\begin{array}{c}\mathrm{CHCl}_{3} \\
\mathrm{MIC}(\mu \mathrm{g} / \mathrm{mL}) \\
\end{array}$ & $\begin{array}{c}\mathrm{MeOH} \\
\mathrm{MIC}(\mu \mathrm{g} / \mathrm{mL})\end{array}$ \\
\hline \multicolumn{4}{|l|}{ Anacardiaceae } \\
\hline Anacardium humile & Leaf & 2000 & 500 \\
\hline Mangifera indica & Leaf & 4000 & 2000 \\
\hline \multicolumn{4}{|l|}{ Apocynaceae } \\
\hline Harcornia speciosa & Leaf & 2000 & 4000 \\
\hline $\begin{array}{l}\text { Bromeliaceae } \\
\text { Ananas ananassoides }\end{array}$ & Lef & 2000 & 2000 \\
\hline Bromélia balansal & Fruits & 2000 & 2000 \\
\hline \multicolumn{4}{|l|}{ Compositae } \\
\hline Articun lappa & Leaf & NR & 4000 \\
\hline \multicolumn{4}{|l|}{ Cucurbitaceae } \\
\hline Caesalpinia ferrea & Leaf & NR & 4000 \\
\hline \multicolumn{4}{|l|}{ Dilleneaceae } \\
\hline Curatella americana & Bark & 62.5 & 500 \\
\hline Davilla elliptica & Leaf & 62.5 & 4000 \\
\hline Davilla nitida & Leaf & 125 & 2000 \\
\hline \multicolumn{4}{|l|}{ Eriocaulaceae } \\
\hline Eriocaulon ligulatum & Scapes & 1000 & 4000 \\
\hline Leiothrix flavescens & Scapes & 125 & 2000 \\
\hline Syngonanthus artrothichus & Chapter & 4000 & NR \\
\hline Syngonanthus artrothichus & Scapes & 1000 & NR \\
\hline Syngonanthus macrolepsis & Scapes & 1000 & 4000 \\
\hline \multicolumn{4}{|l|}{ Euphorbiaceae } \\
\hline Alchornea glandulosa & Leaf & 4000 & 4000 \\
\hline Alchornea triplinervia & Leaf & 4000 & 4000 \\
\hline \multicolumn{4}{|l|}{ Leguminosae } \\
\hline Indigofera suffruticosa & Leaf & 1000 & 125 \\
\hline Indigofera truxilensis & Leaf & NR & 500 \\
\hline \multicolumn{4}{|l|}{ Loganiaceae } \\
\hline Strychnos pseudoquina & Leaf & 125 & 4000 \\
\hline \multicolumn{4}{|l|}{ Malpighiaceae } \\
\hline Byrsonima basiloba & Leaf & 125 & 250 \\
\hline Byrsonima coccolobifolia & Leaf & NR & 1000 \\
\hline Byrsonima crassa & Leaf & 125 & 1000 \\
\hline Byrsonima crassa & Bark & 2000 & 1000 \\
\hline Byrsonima fagifolia & Leaf & 62.5 & 500 \\
\hline Byrsonima intermedia & Leaf & 250 & 2000 \\
\hline \multicolumn{4}{|l|}{ Melastomataceae } \\
\hline Miconia cabuku & Leaf & 250 & 31.2 \\
\hline Miconia rubiginosa & Leaf & 250 & 31.2 \\
\hline Mouriri pusa & Leaf & 4000 & 2000 \\
\hline \multicolumn{4}{|l|}{ Nyctaginaceae } \\
\hline Guapira noxia & Leaf & $>250$ & 31.2 \\
\hline Neea theifera & Leaf & 62.5 & 250 \\
\hline \multicolumn{4}{|l|}{ Simaroubaceae } \\
\hline Quassia amara & Bark & 250 & NR \\
\hline Vitaceae & & & \\
\hline \multirow{2}{*}{\multicolumn{4}{|c|}{ Vochysiaceae }} \\
\hline & & & \\
\hline Qualea grandiflora & Bark & 62.5 & 1000 \\
\hline Qualea multiflora & Bark & 125 & 500 \\
\hline
\end{tabular}

(NR) - Not Realized

$\left(\mathrm{CHCl}_{3}\right)$ - Chloroform Extracts.

$(\mathrm{MeOH})$ - Methanol Extracts.

of plants were collected at Road of the Brejinho of Nazaré, State of Tocantins, Brazil and the species was identified by Dr. Eduardo Ribeiro dos Santos of Tocantins University. All voucher specimens were deposited at the Herbarium of the Universidade do Tocantins in Tocantins, Brazil.

\section{Preparation of extracts and fractions}

The air-dried and powdered leaves were exhaustively extracted with chloroform and methanol, successively at room temperature $(48 \mathrm{~h}$ for each solvent). Solvents were evaporated at temperature of $60{ }^{\circ} \mathrm{C}$ under reduced pressure to yield the chloroform extract and methanol extract.

\section{Antitubercular activity assay}

The antitubercular activity of crude extracts was determined using the MABA (Collins \& Franzblau, 1997) as the analytical method. Stock solutions of the tested compounds were prepared in dimethyl sulfoxide 
(Collins \& Franzblau, 1997) and were diluted in Middlebrook 7H9 (Difco) broth supplemented with oleic acid, albumin, dextrose, and catalase (OADC enrichment - BBL/Becton-Dikinson, Sparks, MD, USA) to obtain final sample concentrations ranges of 0.15 to $1600 \mu \mathrm{g} / \mathrm{mL}$. Isoniazid was solubilized with distilled water according to the manufacturers' recommendations (Difco laboratories, Detroit, MI, USA) and used as a positive control drug. M. tuberculosis $\mathrm{H}_{37} \mathrm{Rv}$ ATCC 27294 was grown for 7 to 10 days in Middlebrook 7H9 supplemented with OADC added of $0.05 \%$ Tween 80 to avoid clumps. Suspensions were prepared and their turbidities matched to a McFarland no. 1 (turbidity standard). After further dilution of 1:25 in Middlebrook 7H9 supplemented with OADC, the inoculum was added to each well of the 96 well microtiter plate (Falcon 3072; Becton Dickinson, Lincoln Park, NJ) together with the compounds. Samples were set up in triplicate. Cultures were in incubated for 7 days at $37^{\circ} \mathrm{C}$, and after additioned Alamar Blue for the reading. The minimum inhibitory concentration (MIC) was defined as the lowest concentration resulting in $90 \%$ inhibition of growth of $M$. tuberculosis (Collins \& Franzblau, 1997) measuring the fluorescence (excitation/emission of 530/590 nm filters respectively) in a SPECTRAfluor Plus (Tecan) (Franzblau et al., 1998). For standard test, the MIC value of isoniazid was determined each time. The acceptable MIC of Isoniazid ranged from 0.015 to $0.05 \mu \mathrm{g} / \mathrm{mL}$ (Collins \& Franzblau, 1997).

\section{RESULTS AND DISCUSSION}

The MIC values of 37 plant extracts against $M$. tuberculosis are shown in Table 1.

Tosun (2004) considered inactive the plant extracts that could not prevent growth of M.tuberculosis up to concentration of $200 \mu \mathrm{g} / \mathrm{mL}$ and according to $\mathrm{Gu}$ (2004) the MIC value of $\leq 128 \mu \mathrm{g} / \mathrm{mL}$ is defined as active against $M$. tuberculosis. From analyzed extracts, 12 chloroform extracts were considered promising and the MIC was ranged within 62.5 to $125 \mu \mathrm{g} / \mathrm{mL}$. In these extracts, probably, the chloroform enabled the extraction of the apolar compounds, their lipophilic character allowed to penetrate the mycobacterial cell wall, determining the antimycobacterial activity. The terpenes are the apolar compounds frequently found within Cerrado plants and that anti-tuberculosis activity was extensively described (Copp, 2003; Aguiar et al., 2005). However, it was also verified prominent anti- $M$. tuberculosis activity in 4 methanol extracts with MIC value ranging from 31.2 to $125 \mu \mathrm{g} / \mathrm{mL}$. The phenolic polar compounds and alkaloids with antimycobacterial activity are frequently isolated from Cerrado plants that also can pass through the cell wall of the bacteria (Aguiar et al., 2005).

These results suggest that the Brazilian "Cerrado" may be a source of plants that have active
anti-M. tuberculosis constituents that can be extracted by polar and apolar solvents.

Further studies on isolation of bioactive fractions present in the active extracts of these plants will permit the establishment of a correlation between structure and antitubercular activity.

\section{ACKNOWLEDGEMENTS}

This research was financially supported by FAPESP/BIOTA and CNPq.

\section{REFERENCES}

Aguiar RM, David JP, David JM 2005. Unusual naphthoquinones, catechin and triterpene from Byrsonima microphylla. Phytochemistry 66: 23882392.

Almeida SP, Proença CEB, Sano SM, Ribeiro JF 1998. Cerrado: espécies vegetais úteis. In: Sano SM, Almeida SP (eds). Planaltina, Distrito Federal, Brazil, p. 38-39.

Cantrell CL, Franzblau SG, Fischer NH 2001. Antimycobacterial plant terpenoids. Planta Med 67: $1-10$.

Collins LA, Franzblau SG 1997. Microplate alamar blue assay versus BACTEC 460 system for high-throughput screening of compounds against Mycobacterium tuberculosis and Mycobacterium avium. Antimicrob Agents Chemother 41: 1004-1009.

Copp BR 2003. Antimycobacterial natural products. Nat Prod Rep 20: 535-557.

Franzblau SG, Witzig RS, McLaughlin JC, Torres P, Madico G, Hernandez A, Degnan MT, Cook MB, Quenzer VK, Ferguson RM, Gilman RH 1998. Rapid, low-technology MIC determination with clinical Mycobacterium tuberculosis isolates by using the microplate alamar blue assay. J Clin Microbiol 36: 362-366.

Gu JQ, Wang Y, Franzblau SG, Montenegro G, Yang D, Timmermann BN 2004. Antitubercular constituents of Valeriana laxiflora. Planta Med 70: 509-514.

Higuchi CT, Pavan FR, Sannomiya M, Vilegas W, Leite SRA, Sacramento LVS, Sato DN, Leite CQF. 2008. Triterpenes and antitubercular activity of Byrsonima crassa. Quim Nova 31: 1719-1721.

Mendonça RC, Felfili JM, Walter BMT, Silva Jr MC 1998. Flora vascular do Cerrado. In: Sano SM, Almeida SP. (eds). Planaltina, Distrito Federal, Brazil, p. 286556.

Tosun F, Akyüz Kizilay C, Sener B, Vural M, Palittapongarnpim P 2004. Antimycobacterial screening of some Turkish plants. J Ethnopharmacol 95: 273-275.

Tripathi RP, Tewari N, Dwivedi N, Tiwari VK 2005. Fighting tuberculosis: an old disease with new challenges. Med Res Rev 25: 93-131. 